\title{
NERVE CONDUCTION STUDY IN PATIENTS WITH SICKLE CELL DISEASE
}

\author{
Satarupa Dash', Atanu Kumar Thakur ${ }^{2}$
}

${ }^{1}$ Senior Resident, Department of Physiology, VIMSAR, Burla, Odisha. 2Senior Resident, Department of Medicine, VIMSAR, Burla, Odisha.

\begin{abstract}
AIM

To determine the peripheral nervous system involvement in patients with sickle cell disease through nerve conduction study.

\section{METHODOLOGY}

23 patients $(M=9, F=5)$ with established sickle cell disease were taken in the present study for nerve conduction study. Sample was collected from Department of Medicine and study was conducted in Department of Physiology, Veer Surendra Sai Medical Science and Research between June 2014 and Jan 2015. All were within the age group 14-45 yrs. They were closely scrutinised for sign and symptom of clinical neuropathy. The control group contains 25 normal persons within the same age group (M=20, F=5). A comparative study of nerve conduction velocity were done between sickle cell disease patients with neuropathy and without neuropathy and also compared with normal laboratory value. The study includes the following things, a) Motor nerve conduction study, b) Sensory nerve conduction study, c) F wave and d) Terminal latency.
\end{abstract}

\section{RESULTS}

In the present study, Motor Nerve Conduction Velocity (MNCV meter/sec) and Sensory Nerve Conduction Velocity (SNCV meter/sec) in different nerves were done in sickling patients. The peripheral nervous system involvement was detected in 10 patients compared with laboratory value. The mean MNCV was delayed in patients with neuropathy when compared with sickle cell disease without neuropathy and also with normal laboratory value $(\mathrm{p}<0.001)$. Similarly, mean SNCV was delayed in patients with neuropathy when compared with sickle cell disease without neuropathy and also with normal laboratory value ( $p<0.001)$. It was observed that terminal latency of MNCV is prolonged $(\mathrm{p}<0.05)$ in sickling patient with neuropathy. Prolonged $\mathrm{F}$ wave latencies were observed in 4 (7.84\%).

\section{CONCLUSION}

The sickle cell disease, an inherited disorder is said to be having worldwide distribution, but its prevalence is restricted to some areas of few developing countries. In India, sickle cell disease is common in Western Odisha. Recurrent vaso-occlusive crisis is a well-established complication of sickle cell disease. The nerve roots and peripheral nerves may likewise be damaged due to vaso-occlusive crisis. Nerve conduction studies are recommended in routine examination to diagnose early neuropathy in SCD patients without neurological symptoms. They can also be used to test the progression and effect of treatment in patients having sickle cell disease with neuropathy.

\section{KEYWORDS}

Sickle Cell Disease, Nerve Conduction Velocity, Motor Nerve Conduction Velocity, Sensory Nerve Conduction Velocity.

HOW TO CITE THIS ARTICLE: Dash S, Thakur AK. Nerve conduction study in patients with sickle cell disease. J. Evolution Med. Dent. Sci. 2016;5(70):5067-5070, DOI: 10.14260/jemds/2016/1151

\section{INTRODUCTION}

Sickle cell haemoglobinopathy is an inherited disorder of haemoglobin synthesis where a molecule of glutamic acid is substituted by valine at $6^{\text {th }}$ position of $\beta$ chain of the haemoglobin molecule. The first case was described in a Jamaican student by Dr. J B Harrick (1910) and the disease was thought to be confined to Negro race.(1) Later on its worldwide distribution is studied. In India, Sukla and Solanki reported its prevalence in central India.(2) Nanda B K and Panda G K et al reported sickle cell haemoglobinopathy in Western Odisha.(3) It is more common in certain castes like Agharia, Kulta, etc.(3)

Sickle cell disease is a multisystem disease, the clinical manifestation of which includes chronic haemolysis, repeated infection, growth retardation in addition to acute

Financial or Other, Competing Interest: None.

Submission 12-06-2016, Peer Review 04-08-2016,

Acceptance 10-08-2016, Published 31-08-2016.

Corresponding Author:

Dr. Satarupa Dash,

A-31, L-4, JM Colony,

Sambalpur, Odisha.

E-mail: satarupa.sbp@gmail.com

DOI: $10.14260 /$ jemds $/ 2016 / 1151$ life-threatening complications called crisis. The process of vaso-occlusion, distal ischaemia and further sickling in SCD leads to micro-infarction in various organs. The nervous system may also get damaged due to micro-infarcts. Various central nervous system lesion like cerebral thrombosis, intracranial haemorrhage, subarachnoid haemorrhage, cranial nerve palsies and focal neurological deficit have been described in SCD. (4) The nerve roots and peripheral nerves may likewise be damaged due to diffuse occlusion of the vasonervosum. $(4,5)$

Many workers have shown that SCD is widely prevalent in Western Odisha.(6) It has been reported that about 15.56\% cases attending VSS Medical College and Hospital, Burla suffered from SCD.(7)

Within last two decades, several studies have been carried out in this zone dealing with various aspect of the disease. Though many patients of SCD attended the Hospital, no study has been taken to find out the involvement of peripheral nerves in SCD. Therefore, the present work has been taken up to study the involvement of peripheral nerve in SCD patients. So our objective of the study is to find the correlation of SCD with neuropathy through Nerve Conduction Velocity (NCV) study. 


\section{MATERIAL AND METHODS}

The study was carried out in the Department of Physiology and Medicine of Veer Surendra Sai Medical Science and Research, Burla.

\section{METHOD}

23 patients of sickle cell disease (Detected by positive sickling test) were closely scrutinised for signs and symptoms suggestive of peripheral neuropathy. All are within the age group of 14-45 years ( $M=9, F=5)$. A thorough examination of neurological complication in sickle cell disease was made in each case.

Inclusion Criteria for Neurological Diagnosis of Peripheral Neuropathy (PN)

1. Diminution or absence of vibration sense in either extremities with or without sensory deficit.

2. Diminution or absence of ankle jerk with or without changes in their deep tendon reflexes.

\section{Exclusion Criteria}

1. Patients with sign and symptoms pertaining to heavy metal poisoning (Arsenic, LEAD).

2. Metabolic abnormality (Diabetes Mellitus, Uraemia).

3. Peripheral neuropathy due to other systemic causes.

4. Family history of familial neurological disorder.

The control group (Group A) contains 25 normal persons within the same age group $(M=20, F=5)$.

\section{The Cases are divided into 2 Groups}

1. Group B - Sickle cell patient with neuropathy.

2. Group C - Sickle cell patient without neuropathy.

A conventional electrophysiological study of peripheral nerves were performed in all subjects of case and control group. A comparative study of nerve conduction velocity were done between SCD patients with neuropathy (Group B) and without neuropathy (Group C) and the control group (Group A).

\section{The Nerve Conduction Study Include}

1. Motor Nerve Conduction Velocity (MNCV).

2. Sensory Nerve Conduction Velocity (SNCV).

3. F wave.

4. Distal latency.

The instrument used was Neurostim-NS2 of Medicaid.

All statistical analysis were performed using statistical package for social science SPSS (version 16) for windows. All parametric variables were expressed as mean \pm SD. One-Way
ANOVA was performed as the test of significance in case of age and BMI distribution. A comparative study was done using paired t-test in between case and control group. $\mathrm{P}$ values of less than 0.001 were considered as statistically significant.

\section{RESULTS}

23 cases of established SCD were taken in the present study. A comparative electrophysiological study had been done between SCD patients with neuropathy (Group B=10) and without neuropathy (Group $\mathrm{C}=13$ ) and the control group (Group A=25).

All the subjects are within the age group of 14-45 years. The subjects were of similar age and BMI (Body Mass Index).

\begin{tabular}{|c|c|c|}
\hline Groups & $\begin{array}{c}\text { Age (Years) } \\
\text { Mean } \pm \text { SD }\end{array}$ & $\begin{array}{c}\text { BMI (Kg/m2) } \\
\text { Mean } \pm \text { SD }\end{array}$ \\
\hline $\mathrm{A}$ & $47.52 \pm 4.73$ & $25.20 \pm 4.58$ \\
\hline $\mathrm{B}$ & $49.13 \pm 6.10$ & $25.41 \pm 2.98$ \\
\hline $\mathrm{C}$ & $48.49 \pm 4.83$ & $23.21 \pm 2.98$ \\
\hline \multicolumn{3}{|c|}{ Statistical Analysis: P Value } \\
\hline $\mathrm{A} \mathrm{v} / \mathrm{s} \mathrm{B}$ & $0.168 \mathrm{NS}$ & $2.000 \mathrm{NS}$ \\
\hline $\mathrm{A} \mathrm{v} / \mathrm{s}$ C & $0.486 \mathrm{NS}$ & $0.424 \mathrm{NS}$ \\
\hline $\mathrm{B}$ /s C & $2.000 \mathrm{NS}$ & $0.300 \mathrm{NS}$ \\
\hline \multicolumn{3}{|c|}{ A= Control Group P < 0.001 = Significant } \\
B= SCD with Neuropathy NS= Not Significant \\
C = SCD without Neuropathy \\
\hline \multicolumn{3}{|c|}{ Table 1: Shows the Characteristic Age and BMI } \\
Distribution of the Study Subjects \\
\hline
\end{tabular}

Out of the 23 cases 17 (73.91\%) suffer from fever, 12 $(52.17 \%)$ cases have generalised weakness, $14(60.86 \%)$ have abdominal pain, 7 cases have jaundice and joint pain respectively. One case has cranial nerve palsy and 10 cases $(43.47 \%)$ have peripheral neuropathy.

\begin{tabular}{|c|c|c|}
\hline Symptoms & No. of Cases & Percentage \\
\hline Fever & 17 & 73.91 \\
\hline $\begin{array}{l}\text { Generalised } \\
\text { Weakness }\end{array}$ & 12 & 52.17 \\
\hline Abdominal Pain & 14 & 60.86 \\
\hline $\begin{array}{l}\text { Pain in Joints and } \\
\text { Bone }\end{array}$ & 7 & 30.43 \\
\hline Jaundice & 7 & 30.43 \\
\hline Cranial Nerve Palsies & 1 & 4.34 \\
\hline Radiculopathy & 2 & 8.69 \\
\hline $\begin{array}{l}\text { Peripheral } \\
\text { Neuropathy }\end{array}$ & 10 & 43.47 \\
\hline Vertigo & 2 & 8.69 \\
\hline
\end{tabular}

\begin{tabular}{|c|c|c|c|c|c|c|}
\hline \multicolumn{2}{|c|}{ Mean MNCV m/sec } & \multicolumn{3}{c|}{ P Value } \\
\hline & A(n=25) & B(n=10) & C(n=13) & AVsB & AVsC & CVsB \\
\hline Median N & $57.2 \pm 4.0$ & $46.0 \pm 0.36$ & $53.9 \pm 0.25$ & $\mathrm{P}<0.001$ & $\mathrm{P}>0.05 \mathrm{NS}$ & $\mathrm{P}<0.001$ \\
\hline Sural N & $50.1 \pm 4.1$ & $41.0 \pm 0.37$ & $49.62 \pm 0.33$ & $\mathrm{P}<0.001$ & $\mathrm{P}>0.05 \mathrm{NS}$ & $\mathrm{P}<0.001$ \\
\hline \multicolumn{5}{|c|}{ A=Control Group, $\mathrm{P}<0.001=$ Significant } \\
B= SCD with Neuropathy, NS= Not Significant \\
C = SCD without Neuropathy \\
\hline
\end{tabular}

From the Table No. 3 it was obvious that the MNCV of the control (A) bears significant correlation with SCD patients having neuropathy (B), whereas it is statistically insignificant when compared to the patients without neuropathy (C). 


\begin{tabular}{|c|c|c|c|c|c|c|}
\hline Nerve Studied & \multicolumn{3}{|c|}{ Mean SNCV m/sec } & P Value \\
\hline & A (n=25) & B (n=10) & C (n=13) & AVsB & AVsC & CVsB \\
\hline Median N & $57.6 \pm 5.2$ & $46.1 \pm 0.77$ & $56.26 \pm 0.33$ & $\mathrm{P}<0.001$ & $\mathrm{p}>0.05 \mathrm{NS}$ & $\mathrm{P}<0.001$ \\
\hline Sural N & $54.6 \pm 5.8$ & $45.9 \pm 0.62$ & $54.39 \pm 0.35$ & $\mathrm{P}<0.001$ & $\mathrm{p}>0.05 \mathrm{NS}$ & $\mathrm{P}<0.001$ \\
\hline \multicolumn{5}{|c|}{ A $=$ Control Group, $\mathrm{P}<0.001=$ significant } \\
BCD with Neuropathy, NS= Not Significant \\
C =SCD without Neuropathy \\
\hline
\end{tabular}

In the Table 5, it was found that the terminal latencies of SCD with neuropathy (B) is prolonged than SCD without neuropathy (C) and control group (A). It is statistically significant.

\begin{tabular}{|c|c|c|c|c|c|c|}
\hline Nerve Studied & \multicolumn{3}{|c|}{ Mean Distal Latency m/sec } & P Value \\
\hline & A (n=25) & B (n=10) & C (n=13) & AVsB & AVsC & CVsB \\
\hline Median N & $2.07 \pm 0.30$ & $2.82 \pm 0.02$ & $2.08 \pm 0.23$ & $\mathrm{P}<0.001$ & $\mathrm{p}>0.05 \mathrm{NS}$ & $\mathrm{P}<0.001$ \\
\hline Sural N & $3.89 \pm 0.30$ & $4.73 \pm 0.02$ & $4.01 \pm 0.12$ & $\mathrm{P}<0.001$ & $\mathrm{p}>0.05 \mathrm{NS}$ & $\mathrm{P}<0.001$ \\
\hline \multicolumn{5}{|c|}{ B=Control Group, P $<0.001=$ Significant } \\
B=D with Neuropathy, NS = Not Significant \\
C = SCD without Neuropathy \\
\hline
\end{tabular}

The Table No. 6 reveals that the $F$ wave latency is prolonged in SCD with neuropathy (A) when compared with control value (B). It is statistically significant.

\begin{tabular}{|c|c|c|}
\hline $\begin{array}{l}\text { Group } \\
\text { Studied }\end{array}$ & $\begin{array}{l}\text { F Wave } \\
\text { Latency } \\
\text { (m. sec) }\end{array}$ & $P$ value \\
\hline Control (A) & $28.3 \pm 2.00$ & \multirow{2}{*}{$\begin{array}{c}\mathrm{P}<0.05 \\
\text { Significant }\end{array}$} \\
\hline $\begin{array}{c}\text { Sickle cell patient with } \\
\text { neuropathy (B) }\end{array}$ & $32.24 \pm 0.44$ & \\
\hline
\end{tabular}

\section{DISCUSSION}

The sickle cell disease, an inherited disorder of Haemoglobin synthesis is the most common structural haemoglobinopathy.(8) It is caused by the mutation in beta globin gene that changes the $6^{\text {th }}$ amino acid from glutamic acid to valine.(8) It is more common in Agaria and Kulta family.(6) Consanguineous marriage in these castes increase the risk of SCD. Vaso-occlusion causes protean manifestation. Intermittent episode of vaso-occlusion in connective and musculoskeletal structure produce ischaemia manifested by acute pain, tenderness, fever, tachycardia and anxiety. In patients with sickle cell disease the peripheral nervous system might be affected, but during the early state clinical manifestation may not be obvious. Recurrent vaso-occlusive crisis may increase the risk of peripheral neuropathy. ${ }^{(9)}$ Though the central nervous system manifestation of SCD is well-documented, peripheral nerve involvement has not received adequate attention. In some SCD, lead poisoning and sodium cyanide poisoning could have been responsible for the neuritis.(10) It is more likely that SCD per se may damage the nerve or make them more susceptible to the neurotoxicity of other agent. Thus, the issue of pathological involvement of peripheral neuritis in SCD is yet unresolved. Inadequate literature is available dealing with the peculiar aspect of the disease. As sickle cell disease is prevalent in Western Odisha, we have selected this topic for present study.(10) Neuropathic pain exists in SCD. Valid screening tools can identify patients that would benefit from existing and future neuropathic pain therapies and could determine the impact of these therapies.(11)
23 cases of established SCD were taken in the study. The Motor Nerve Conduction Velocity (MNCV) and Sensory Nerve Conduction Velocity (SNCV) in different nerves studied were compared with normal laboratory value. The MNCV was delayed in SCD patients with neuropathy versus the normal laboratory value and SCD patients without neuropathy. Similarly, SNCV was delayed in SCD patients with neuropathy versus the normal laboratory value and SCD patients without neuropathy. This finding are similar to previous study.(12) It was observed that the terminal latency of MNCV is prolonged. This suggested possible mechanism is thought to be vasoocclusion and hypoxic ischaemic to nerve. These findings were similar to previous study.(12) F wave latency was prolonged in patient with radiculopathy. This may suggest the same mechanism of vaso-occlusion for radiculopathy. This root involvement in SCD was observed in a previous study.(13)

\section{CONCLUSION}

Pain of SCD has been thought to be related to visceral and somatic tissue injury subsequent to vaso-occlusion events, another component of pain of SCD may be related to neuropathic processes. Vaso-occlusive crisis in the form of bone and joint pain, recurrent leg ulcer are recognised complication of sickle cell disease.(14) Neurological involvement due to vaso-occlusion lead to peripheral nerve involvement. Hypoxic ischaemia due to vaso-occlusion by SCD is the possible mechanism of peripheral nerve involvement. Some of the mechanisms related to neuropathic pain involve CaMKII and PKC, which may be relevant to the pain of SCD.(15) Mononeuropathy was dominant presentation. The study has revealed neurophysiological evidence of neuropathic changes in SCD. Though the mechanism responsible remain unclear, this complication may contribute to morbidity in these patients.(16) We recommend that evidence of peripheral neuropathy should be sought in SCD patient and managed appropriately. Nerve conduction study may be recommended in routine examination to diagnose early neuropathy in SCD patients without neurological symptoms. They can also be used to test the progression and effect of treatment in patients having sickle cell disease with neuropathy. 


\section{ACKNOWLEDGEMENTS}

We are thankful to Dr. (Prof) M Acharya, HOD, Dept. of Neurology for his guidance and support. We also thank our HOD, Dept. of Physiology, Dr. (Prof) A K Misra for his immense support. We thank all the staffs and laboratory technician (Dept. of Physiology and Medicine); without their help we would not be able to complete the work. We thank all the patients who believed and helped us during the study period.

\section{REFERENCES}

1. Herrick JB. Peculiar elongated and sickle-shaped red blood corpuscles in a case of severe anemia. 1910. Arch Int Med1910;6(5):517-21.

2. Sukla BN, Solanki BR. Sickle cell trait in India. Lancet 1985;1:297-98.

3. Nanda BK, Panda GK, Naik UP, et al. Prevalence of sickle cell disease in Western Orissa. J Int Med Asso 1987;48(2):150-151.

4. Rothman SM, Fulling KH, Nelson JS. Sickle cell anemia and central nervous system infarction: a neuropathological study. Ann Neurology 1986;20(6):684-90.

5. Okuyucu EE, Turhanoglu A, Duman T, et al. Peripheral nervous system involvement in patients with sickle cell disease. Eur J Neurol 2009;16(7):814-8.

6. Praharaj KC, Mohanty KD, Kar RS, et al. Sickle cell disorder in Orissa. Indian J Pediatrics 1987;8(1):566-567.

7. Kar BC, Devi S, Dash KC, et al. A study on incidence of sickle cell disease and its complication. Trans Roy Trop Med Hygine1987;8(3):122-123.
8. Sickle cell hemoglobin disorder. In: Kasper D, Fauci A, Hauser S, et al. Harrison's principle of internal medicine. 19th edn. New York: McGraw-Hill Education 2015: 852-856.

9. Wilkie DJ, Molokie R, Boyd-Seal D, et al. Patient-reported outcomes: descriptors of nociceptive and neuropathic pain and barriers to effective pain management in adult outpatients with sickle cell disease. J Natl Med Assoc 2010;102(1):18-27.

10. Kar BC, Kulozik AE, Satapathy RK, et al. Sickle cell disease in Orissa state, India. Lancet1986;2(8517):1198-201.

11. Brandow AM, Farley RA, Panepinto JA. Neuropathic pain in patients with sickle cell disease. Pediatr Blood Cancer 2014;61(3):512-7.

12. Peterson CM, Cerami A, et al. Neurological manifestation of sickle cell disorder. Ann Int Med 1984;11(2):569-76.

13. Serjeant GR, Ashcroft MT, Serjeant BE, et al. The clinical features of sickle-cell-thalassaemia in Jamaica. $\mathrm{Br} \mathrm{J}$ Haematol 1973;24(1):19-30.

14. Disorder of hemoglobin synthesis. In: Saxena R, Pati HP, Mahapatra M, et al. De Gruchy clinical hematology in medical practice. $6^{\text {th }}$ edn. Wiley Blackwell 2012:120-133.

15. Wang ZJ, Wilkie DJ, Molokie R. Neurobiological mechanisms of pain in sickle cell disease. Hematology Am Soc Hematol Educ Program 2010;2010:403-8.

16. Gadallah N, Hefnawy HE, Ahmed S, et al. Trigeminal nerve electrophysiological assessment in sickle cell anemia: correlation with disease severity and radiological findings. Egypt Rheumatol Rehabil 2015;42(2):73-9. 